\title{
STRATEGI KREATIF DALAM PROMOSI SEKUTU KOPI MELALUI MEDIA SOSIAL INSTAGRAM
}

\author{
D ea Christina Sandy², Fitri M urfianti2 \\ 1Prodi S1 Desain Koumunikasi Visual, \\ Fakultas Seni Rupa dan Desain, Institut Seni Indonesia Surakarta \\ Email: deacsandy@ymail.com \\ IInstitut Seni Indonesia Surakarta \\ Email: fitrimurfianti@yahoo.co.id
}

\begin{abstract}
A bstract
Currently, the proliferation of coffee shops has an impact on the competitive promotion strategy to attract customers. Sekutu Kopi is one of the well-known coffee cafes in Surakarta which has the most followers on social media Instagram. Ccreative strategies and message strategies of the Sekutu Kopi in promoting through Instagram are the focus of this study. This study uses creative strategies concept from Z ein M ufarrih, the $5 \mathrm{~W} 1 \mathrm{H}$ concept in designing the message, and uses the indepth interview method to extract data from the informants. The results of this study indicate that the creative strategy in the promotional advertisement of Sekutu Kopi was designed and worked out with a creative brief which would serve as a guideline in making the advertisement. M odern and simple is the strategy and creative concept of Sekutu Kopi. M odern, which means putting forward changes to trends that will continue to change over time and changes in lifestyle. Simple, which means simplicity in the way it is delivered but still has a lot of important information in it, such as a simple logo, the use of illustrations or photos with the typical concept, simple and easy to read typography, layout consistent with Sekutu Kopi characteristics, the use of Sekutu Kopi colors so that the identity is maintained.
\end{abstract}

Keyw ords: C reative Strategy, Instagram, M essage Strategy, P romotion

\begin{abstract}
A bstrak
Semakin menjamurnya warung kopi saat ini berdampak pada persaingan strategi promosi untuk menarik pelanggan. Sekutu Kopi merupakan salah satu cafe Kopi ternama di Surakarta yang memiliki follower terbanyak di media sosial instagramnya. Strategi kreatif dan strategi pesan Sekutu Kopi dalam berpromosi melalui media sosial Instagram menjadi fokus dalam kajian ini. Kajian ini menggunakan strategi kreatif dari Zein Mufarrih, dan konsep $5 \mathrm{~W} 1 \mathrm{H}$ dalam perancangan pesannya serta menggunakan metode wawancara mendalam untuk menggali data dari para informan. Hasil penelitian ini menunjukkan bahwa strategi kreatif dalam iklan promosi Sekutu Kopi dirancang dan dikerjakan dengan creative brief yang akan menjadi pedoman dalam pembuatan iklan tersebut. M odern dan simple merupakan Strategi dan konsep kreatif Sekutu Kopi. Modern yang berarti mengedepankan perubahan terhadap trend yang akan terus berubah seiring berjalannya waktu dan perubahan gaya hidup. Simple yang berarti kesederhanaan dalam cara penyampaian namun tetap memiliki banyak informasi penting didalamnya, seperti logo yang simple, penggunaan ilustrasi atau foto berkonsep khas Sekutu Kopi, tipografi yang sederhana dan mudah dibaca, layout yang konsisten sesuai dengan ciri khas Sekutu Kopi, penggunaan warna-warna khas Sekutu Kopi agar identitas Sekutu Kopi terus terjaga.

Kata Kunci: Strategi Kreatif, Strategi Pesan, Promosi, Instagram
\end{abstract}




\section{PENG ANTAR}

Kopi sudah menjadi bagian dari gaya hidup masyarakat modern masa kini. Hal ini semakin mendorong menjamurnya warung atau cafe Kopi termasuk di Kota Solo. Persaingan ketat di bisnis ini membuat para pemilik berlomba-lomba menciptakan strategi promosi untuk menarik para pelanggannya. Strategi promosi yang paling populer, efektif, dan hemat biaya saat ini adalah dengan menggunakan media sosial. Menurut Tjiptono promosi adalah suatu komunikasi pemasaran yang dapat diartikan suatu aktifitas pemasaran yang berusaha menyebarkan informasi, mempengaruhi atau membujuk, dan mengingatkan pasar sasaran atas perusahaan atau produknya agar bersedia menerima, membeli, dan loyal pada produk yang ditawarkan perusahaan yang bersangkutan (Tjiptono, 2005).

Sekutu Kopi merupakan salah satu kopi ternama di kota Solo yang memiliki follower terbanyak di media sosial instagramnya. Konsep layout yang unik dan tone warna feed instagram yang konsisten, serta konsep pesannya sangat menarik dan beragam, yang berisi tidak hanya foto kegiatan dalam kedai saja namun juga ada informasi tentang event atau foto aesthetic yang saat ini sedang popular dapat menarik perhatian banyak kaum milenial atau kaum usia produktif yang mengikuti perkembangan jaman. Semua ini dilakukan untuk menjaga agar tetap dekat dengan pelanggannya (wawancara dengan Creative Director Sekutu Kopi, 8 Juli 2019).

Banyaknya pesaing bisnis, serta media sosial yang ramai dimanfaatkan sebagai sarana berpromosi, maka diperlukan sesuatu yang kreatif dalam menciptakan konten iklan promosi agar produk tersebut dapat terlihat lebih menonjol dan berbeda dari produk pesaingnya (Murfianti, 2010). Semakin kreatif suatu iklan, maka iklan semakin mudah dibedakan dari produk pesaing dan lebih mudah diingat oleh audien media sosial. Penelitian ini ingin mengeksplor lebih jauh tentang strategi kreatif yang digunakan Sekutu Kopi dalam promosi melalui media sosial instagram serta strategi pesan yang dilakukannya untuk menciptakan keberhasilan dalam beriklan di media sosial Instagram. 


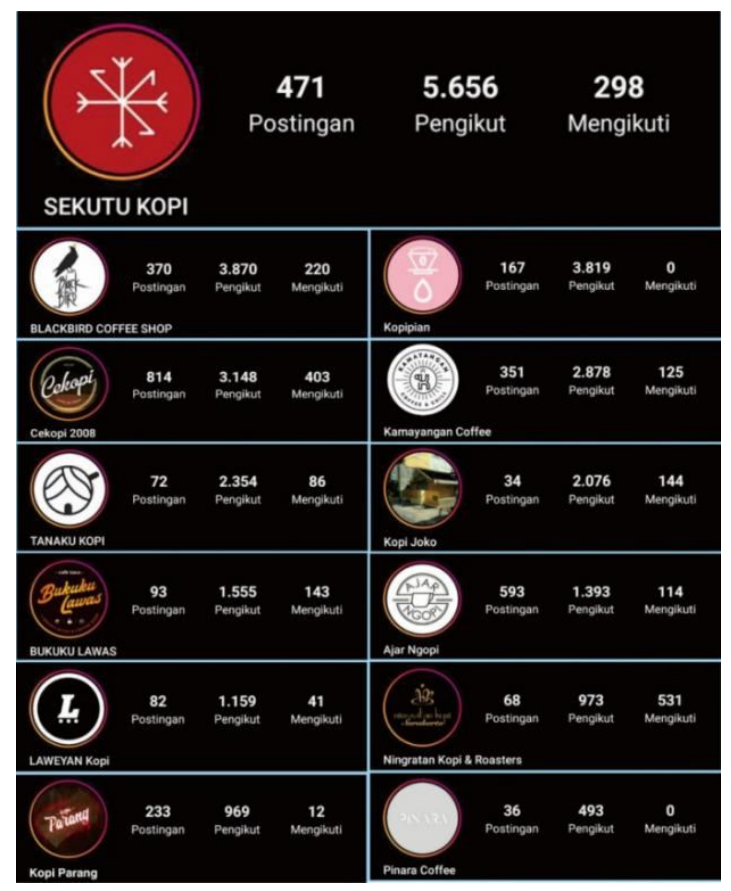

Gambar 1. Perbandingan Sekutu Kopi dengan coffeeshop lain

(Sumber: Dea Christina Sandy,2019)

Berbagai penelitian tentang strategi promosi telah banyak dilakukan, diantaranya yaitu artikel yang ditulis oleh Lim Sook Huey dan Dr. Rashad Yazdanifard (2016) dari Center for Southern New Hampshire University (SNHU) Programs HELP College of Art and Technology Kuala Lumpur Malaysia, yang berjudul “H ow Instagram Can Be U sed as a Tool in Social N etwork Marketing" memberi penjelasan bahwa dengan memanfaatkan instagram maka tujuan untuk mencapai target sasaran pun lebih mudah dan lebih fokus atau terarah. Calon konsumen lebih tertarik dengan iklan yang memiliki banyak gambar (carousel mode) dan video singkat yang menarik dibandingkan dengan iklan yang menggunakan banyak kata-kata. Selanjutnya penelitian yang dilakukan oleh Yudhi Gumbiro Banjaransari (2018) dari Universitas Muhammadiyah Surakarta dengan judul “Pemanfaatan Instagram Sebagai Media Komunikasi Pemasaran O nline Page Down Cloth Maker". Penelitian ini fokus pada pemanfaatan Instagram sebagai media komunikasi pemasaran online dan mengidentifikasi faktor yang mempengaruhi kepercayaan pelanggan pada industri jasa clothing. Sementara penelitian Gita Permatasari (2016) dari Institut Pertanian Bogor berbicara tentang Efektivitas Media Sosial Instagram Sebagai M edia Promosi Produk Olahan Pertanian 'Yoghurt Cimory. Penelitian ini menganalisis efektivitas media promosi melalui Instagram dengan melihat hubungan antara karakteristik follower dengan tingkat keberhasilan media sosial, serta hubungan antara tingkat efisiensi media sosial melalui Instagram dan tingkat efektivitas 
media promosi. Berbeda dari penelitian yang telah dilakukan sebelumnya, kajian ini lebih fikus pada strategi kreatif dan strategi pesan untuk tetep keep in tauch dengan pelanggan setia dan menjaring pelanggan baru.

Untuk menjawab pertanyaan penelitian perlu dipahami beberapa landasan konseptual diantaranya yaitu konsep tentang strategi kreatif, strategi pesan, dan media sosial instagram. Strategi kreatif periklanan merupakan proses untuk menyusun sebuah iklan yang akan ditujukan kepada target audience dengan tujuan untuk memberitahukan tentang sesuatu yang akan dijual baik berupa barang atau jasa dengan kemasan iklan yang baru, unik dan orisinil. Strategi kreatif yang tepat akan menghasilkan iklan yang efektif sesuai dengan target audience yang dituju. Menurut Zein Mufarrih unsur-unsur penting dalam kerja sebuah periklanan yaitu adanya strategi, ide kreatif, pelaksana kreatif, dan media yang tepat (Mufarrih, 2015:107).

Pesan yang akan disampaikan juga menjadi salah satu hal penting yang harus diperhatikan dan juga diperlukan strategi dalam pembuatannya. Strategi pesan dalam promosi merupakan proses untuk menyusun atau merangkai suatu pesan iklan yang akan disampaikan kepada khalayak konsumen. Dengan adanya strategi pesan, maka informasi yang disampaikan akan lebih mudah dimengerti dan diterima dengan baik oleh penerima pesan karena pesan yang disampaikan jelas, tepat sasaran, sesuai dengan konsep yang dibawakan, serta memiliki karakter yang mampu menggambarkan citra suatu merek. Perencanaan pesan dalam suatu iklan sangatlah penting karena melalui pesan yang disampaikan akan tersedia mengenai informasi berisi tentang apa yang diiklankan. Diperlukan sebuah creative brief diawal perencanaan sebuah iklan yang nantinya akan menjadi proses terbentuknya suatu pesan iklan

Iklan melalui media sosial instagram ini dipilih oleh Sekutu Kopi untuk mempromosikan menu-menu di coffeeshopnya. Inti dari periklanan ini terletak pada bagaimana cara menarik minat pengguna media sosial dan masyarakat agar nantinya memberikan perhatian pada sesuatu yang ingin menjadi tujuan (Mufarrih, 2015:4). Media sosial adalah sarana bagi konsumen internet untuk berbagi informasi teks, gambar, video, dan audio satu sama lain dan dengan perusahaan atau perseorangan (Philip \& Keller, 1997:103). Adapun karakteristik media sosial menurut Rulli Nasrulloh yaitu adanya jaringan, informasi, arsip, interaksi, simulasi sosial, dan konten oleh pengguna. (Nasrulloh, 2016:15-16) 
Salah satu media sosial yang paling populer saat ini yaitu Instagram, sebuah layanan media sosial untuk berbagi foto dan video. Foto yang diunggah di sosial media instagram menjadi media visual yang paling disukai yang sering digunakan untuk berkomunikasi antar netizen (Murfianti, 2017). A plikasi ini memungkinkan pemakainya untuk mengunggah foto dan video pada akun Instagram yang dapat disunting (edit) sedemikian rupa oleh pengunggah konten serta mengatur Tags dan informasi lokasi (location information). Posting dari satu akun dapat diunggah ulang oleh orang lain. Selain sebagai sarana untuk memamerkan foto dan video kepada para pemakai Instagram lain, Instagram juga telah dimanfaatkan sebagai alat untuk berpromosi yang berkembang sangat pesat. Fitur pendukung dalam Instagram diantaranya Foto, Video, IGTV, D irect M essages, Story, Likes, Popular. Media sosial instagram sangat mengedepankan elemen-elemen visual yang mendukung promosi iklan seperti Logo, Ilustrasi/ Foto, Caption, dan Layout yang menarik.

Metode penelitian yang digunakan adalah deskriptif-kualitatif dengan teknik pengumpulan data melalui wawancara narasumber, mengobservasi serta mendokumentasikan feed instagram Sekutu Kopi satu tahun terakhir, serta studi berbagai literatur untuk mendukung penelitian. Narasumber dalam penelitian ini ada empat orang yang dianggap berkontribusi besar dalam menajemen Sekutu Kopi, yaitu Creative D irector yang juga bertindak sebagai admin media sosial "Sekutu Kopi" yaitu Donatian Argil Saga Patria (Gege Saga), pemilik Sekutu Kopi sekaligus Marketing Director dan Operational Director Ricky Vernandes dan Carissa Odilia, serta Christopher Dimaz yang bertanggung jawab sebagai Graphic Designer. Masing-masing wawancara berlangsung kurang lebih 60 menit pada hari yang berbeda sesuai dengan waktu yang telah disepakati.

\section{HASIL DAN PEMBAHASAN}

Langkah awal ketika merancang suatu strategi kreatif adalah dengan komunikasi internal antar anggota tim dimana dalam proses ini didiskusikan ide-ide promosi dengan cara yang kreatif. Dalam pembahasan ide, biasanya akan ada creative brief, yaitu sebuah dokumen yang berisi keterangan atau spesifikasi perkembangan kreatif sebuah produk, seperti tujuan, proses, dan tahapnan-tahapannya. Perancangan strategi kreatif untuk promosi oleh Sekutu Kopi menggunakan pendekatan kreatif yaitu melalui promosi dengan pesan-pesan persuasif, sarkasme, gambar, dan foto dengan gaya yang khas.

Pengaplikasian promosi dalam media sosial instagram disampaikan melalui pesan dengan gaya desain yang sesuai dengan target sasaran Sekutu Kopi. Diperlukan beberapa strategi kreatif dalam promosi yang akan dilakukan oleh Sekutu Kopi di Instagram. Dalam 
eISSN 0000-0000

p-ISSN 0000-0000

Vol. 00, A pril 2020

pembuatan strategi kreatif tersebut harus disertai suatu creative brief yang akan menjadi pedoman atau acuan dalam arah kreatif pembuatan iklan promosi di instagram nantinya. Beberapa strategi yang dipakai dalam tahap-tahap penyusunan strategi kreatif dalam kegiatan promosi Sekutu Kopi adalah sebagai berikut:

a. Permasalahan

Berisi tentang deskripsi permasalahan yang ada, kemudian apa yang harus dikerjakan dalam lingkup komunikasi periklanan. Permasalahan umum yang dihadapi Sekutu Kopi adalah perancangan kegiatan promosi, dimana ketika merancang strategi kreatif untuk melakukan promosi di instagram melalui posting seringkali creative director harus menemukan ide-ide baru agar promosi yang dijalankan dapat berjalan dengan lancar. Namun, seringkali ketika ide telah didapatkan, creative director harus mempresentasikan terlebih dahulu kepada marketing director dan operational director. Peran dari creative director sendiri sebenarnya sangat penting ketika melakukan perancangan strategi kreatif. Seperti yang diungkapkan oleh Gege Saga pada wawancara 8 Juli 2019 selaku creative director dan admin media sosial Sekutu Kopi:

"Sebenarnya pemilik (Sekutu Kopi) bisa dan sanggup untuk melakukan perancangan strategi kreatif dan mempromosikan produknya ke target pasar. Tapi, karena ada begitu banyak hal lain yang juga memerlukan perhatian seperti urusan operasional dan marketing, membuat pemilik kewalahan untuk memikirkan segala sesuatunya. Sehingga dengan adanya creative director yang akan melaksanakan tugas mengurusi segala strategi promosi, cara penyampaian kreatif, update media sosial, membalas feedback yang dikirimkan oleh pelanggan ke media sosial Sekutu Kopi tersebut sangatlah membantu pekerjaan pemilik yang juga merangkap sebagai marketing director, operational director, dan barista. Walaupun segala proses kreatif telah diserahkan kepada creative director, setiap desain promosi dan iklan yang dibuat haruslah memenuhi keinginan dari pemilik. Setelah proses pengerjaan desain selesai, creative director dan graphic designer akan mempresentasikan hasil kerjanya kepada pemilik karena mereka juga memiliki wewenang penuh atas segala bentuk promosi dan posting di media sosial usahanya. Pemilik hanya mempercayakan seluruh proses desain dan promosi secara InHouse melalui creative director dan graphic designer saja." (Wawancara Gege Saga, 8Juli 2019)

\section{b. Survey Khalayak}

Berisi tentang pendapat khalayak tentang produk, perilaku konsumen, dan bagaimana sikap khalayak terhadap produk tersebut. Survey ini dapat dilakukan dengan mencari tagar (\#) dengan nama Sekutu Kopi. Dengan munculnya tagar \#sekutukopi pada posting pengunjung kedai yang memposting di media sosialnya mengenai Sekutu Kopi, maka akan dapat diketahui respon masyarakat terhadap produk yang ditawarkan, 
feedback pelanggan, serta interaksi antara Sekutu Kopi dengan Pelanggannya. Seperti yang diungkapkan oleh Gege Saga mengenai hubungan antara Sekutu Kopi dengan pelanggan melalui media sosial Instagram:

“Komunikasi yang terjalin di media sosial kita usahakan sesering mungkin. Lebih seringnya ketika dalam media sosial, gaya bahasa yang digunakan akan lebih santai dan sedikit bernada sarkasme. Jadi, berbeda dengan media sosial bisnis milik produk lain yang akan berusaha seramah mungkin dalam merespon masyarakat. Contoh seperti ketika ada seorang pelanggan yang mengkritik produk kami lantaran isi minuman kopi dalam gelas yang tidak banyak (tidak penuh). Pelanggan tersebut juga membandingkan gelas kopi yang diminumnya dengan tangannya sebagai media pembanding. Saya selaku admin dari Sekutu Kopi kemudian memberikan respon tanggapan yang juga senada dengan apa yang dikeluhkan si pelanggan seperti "walaupun sedikit, yang penting adalah kualitas bukan kuantitas. Walapupun pelayanan di media sosial dapat merespon sedemikian rupa, kami akan mengusahakan pelayanan seramah mungkin ketika pelanggan datang ke kedai kami. Hal ini dilakukan agar pelanggan merasa betah untuk berlama-lama dan mau kembali lagi. Jadi saat berada didalam kedai kami selalu berusaha sebaik mungkin agar pelanggan merasa nyaman." (Wawancara Gege Saga, 8Juli 2019)

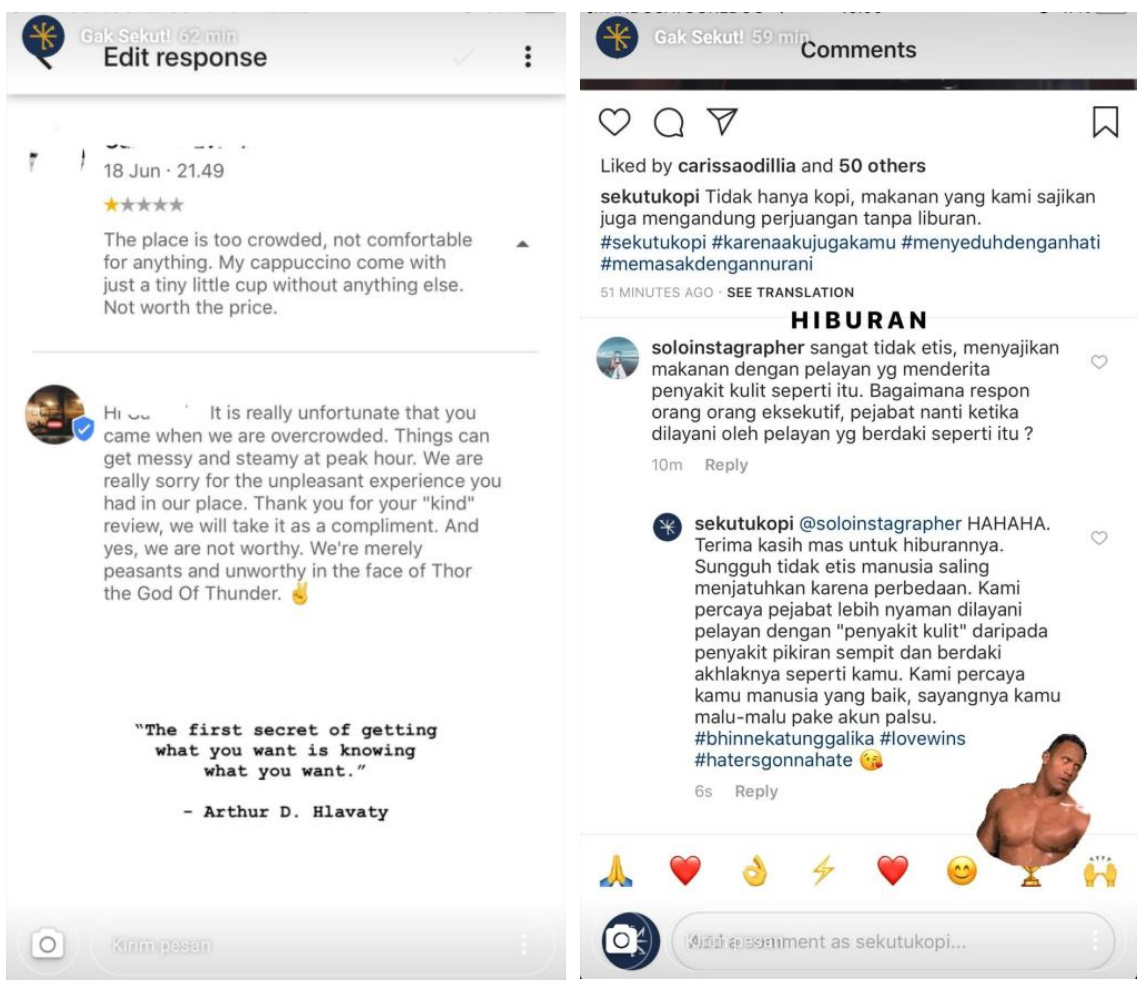

Gambar 2. Interaksi Sekutu Kopi dengan Pelanggan

(sumber: Instagram Sekutu Kopi,2019)

c. Posisi Brand

Posisi brand yang telah dilakukan menunjukkan bahwa Sekutu Kopi ingin menonjolkan sisi kreatif dari aspek promosi melalui media sosial Instagram. Seperti pada foto-foto 
yang diposting, kegiatan dalam kedai yang direkam melalui feed Instagram, maka dapat dilihat dengan jelas bahwa Sekutu Kopi ingin menampilkan mereknya sebagai kedai kopi yang memiliki teknik promosi dan penempatan brand yang tepat. Seperti yang diungkapkan oleh Gege Saga dan Christopher Dimaz mengenai penempatan brand dalam posting Instagram:

“Feed Instagram kita isinya tidak hanya tentang promosi produk kopi saja. Tapi juga beberapa produk selain kopi seperti sidedish, makanan yang kami jual, serta suasana kedai yang kami rasa cocok dengan tema yang digunakan saat itu untuk menarik lebih banyak pelanggan. Hal ini kami lakukan supaya terdapat variasi dalam postingan kami, agar masyarakat mengetahui lebih banyak tentang kami." (Wawancara Gege Saga, 8Juli 2019)

Untuk mendukung posisi brand tersebut, penempatan brand juga menjadi perhatian dari Sekutu Kopi agar menancap diingatan pelanggannya.

“Biasanya untuk penempatan brand bisa diterapkan secara cetak maupun digital. Kalau bidang cetak seperti di gelas cup kopi, sticker, signage, logo didepan kedai, artwork di tembok kedai, penempatan logo diberbagai tempat ini kami lakukan karena dengan begitu pelanggan akan dapat terus mengingat kami melalui visual brand yang kami tampilkan, jadi secara psikologis juga membuat pelanggan menanamkan brand kami dalam pikiran mereka tanpa disadari. Kalau secara digital ya kami tampilkan lewat iklan promosi, feed Instagram, atau lewat posting di Facebook dan profil picture di WhatsA pp" (Wawancara Christopher Dimaz, $10 \mathrm{Juli}$ 2019)

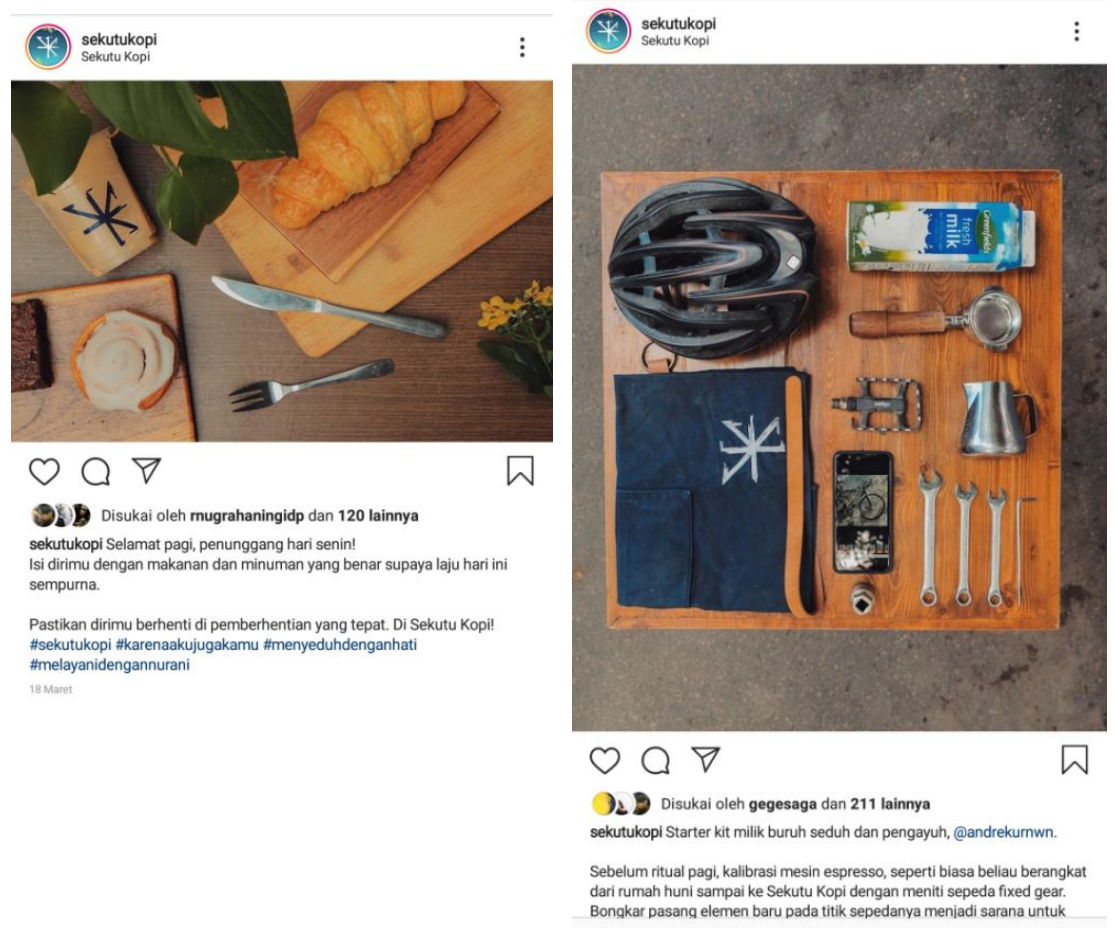

Gambar 3. Feed instagram Sekutu Kopi beserta penempatan brand (Sumber: Instagram Sekutu Kopi, 2019) 
d. Tujuan Komunikasi

Segala bentuk promosi yang dilakukan di media sosial Instagram tentunya bertujuan untuk membuka pandangan masyarakat terhadap Sekutu Kopi agar tidak hanya dikenal sebagai penjual kopi namun juga sebagai space bekerja, menunjukkan kualitas yang ditawarkan, serta kelebihan-kelebihan lain yang membuat Sekutu Kopi tampak berbeda dan menarik bagi masyarakat seperti yang diungkapan oleh Gege Saga dan Ricky Vernandes, bahwa Sekutu Kopi ingin menunjukan eksistensinya dalam dunia kopi serta memberikan pelayanan semaksimal mungkin kepada pelanggan, baik pelayanan di media online maupun secara langsung.

"Kita ingin membangun citra yang baik dengan masyarakat sehingga masyarakat dapat menerima pesan kita dengan baik dan tertarik untuk mencoba melali hospitality yang kita tawarkan seperti yang ditunjukan pada beberapa postingan instagram, kita juga berusaha untuk memberikan kualitas pelayanan dan pengerjaan produk sebaik mungkin karena penilaian pelanggan penting untuk diperhatikan, kami sangat terbuka untuk menerima kritik dan saran yang diberikan apabila hal tersebut dapat membangun kami menjadi lebih baik lagi." (Wawancara Gege Saga, 8Juli 2019)

“Kita juga adakan variasi pada beberapa postingan kami, sehingga tidak hanya mengenai promosi produk yang kami tunjukan namun juga beberapa event khusus yang kami rasa akan menarik bagi pelanggan." (Wawancara dengan Gege Saga, 8Juli 2019)

“Tujuan kami tentunya untuk bisa berkomunikasi langsung dengan pelanggan. Jadi, kami dapat langsung mengerti apa yang dirasakan oleh pelanggan, keinginan mereka seperti apa, maksud mereka mau apa, dan kami juga mudah untuk menyampaikan maksud kami tanpa ada perantara antara kami dengan pelanggan." (Wawancara Ricky Vernandes, 8Juli 2019)

e. Usulan

Respon seperti apa yang diinginkan oleh masyarakat terhadap pesan yang ingin disampaikan. Ide agar target sasaran merespon pesan yang disampaikan seperti telah diungkapkan oleh Gege Saga dan Christopher Dimaz, yaitu ingin memberikan pesan kepada orang yang memang menjadi konsumen mereka bahwa mereka merupakan sebuah kedai kopi lokal yang terbaik dengan cara penyampaian yang unik.

“Kita selalu berusaha agar masyarakat menyadari keberadaan kami sebagai kedai kopi yang nggak hanya menjual kopi tapi juga memperhatikan banyak aspek yang menurut kami akan sangat berpengaruh terhadap penilaian masyarakat ke Sekutu Kopi. Cara kami menyapa konsumen dan memberikan respon terhadap konsumen menjadi salah satu cara kreatif kami dalam menarik hati konsumen dimana kami akan menampilkan karakter yang santai, sarkastik, namun tetap ramah. Dengan memberikan bahan-bahan kopi terbaik, perhatian kami kepada konsumen, hingga respon konsumen terhadap produk kami sangat 
memperhatikan hal-hal tersebut demi keberlangsungan Sekutu Kopi sebagai kedai kopi yang baik." (Wawancara Gege Saga, 8Juli 2019)

"Tidak perlu takut dengan respon masyarakat yang terkadang bisa membuat kami berkecil hati, karena pada dasarnya selera orang juga berbeda-beda. Jadi (kami) tidak bisa mengharapkan respon atau feedback yang selalu positif. Pendapat dari pelanggan akan ditampung dan menjadi bahan evaluasi." (Wawancara Christopher Dimaz, 10 Juli 2019)

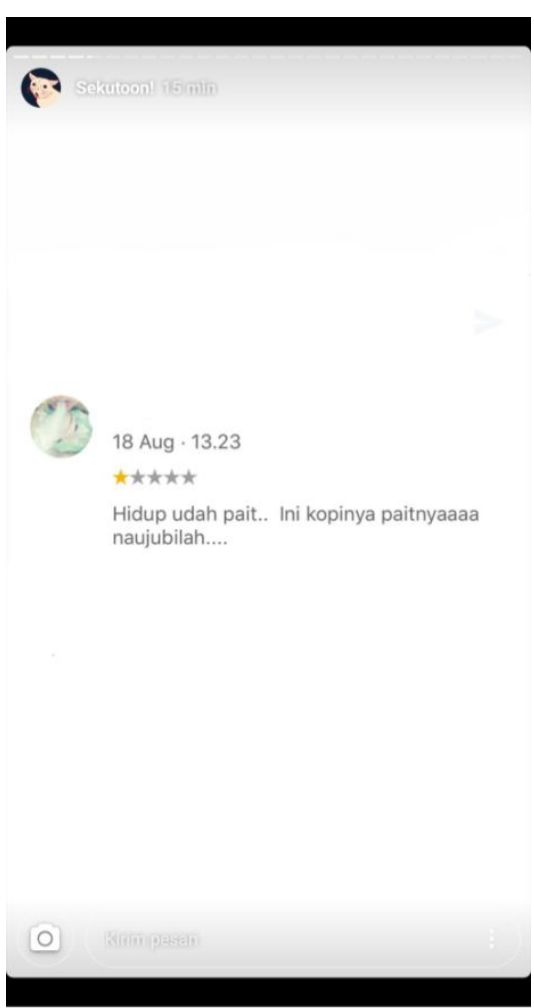

-
()

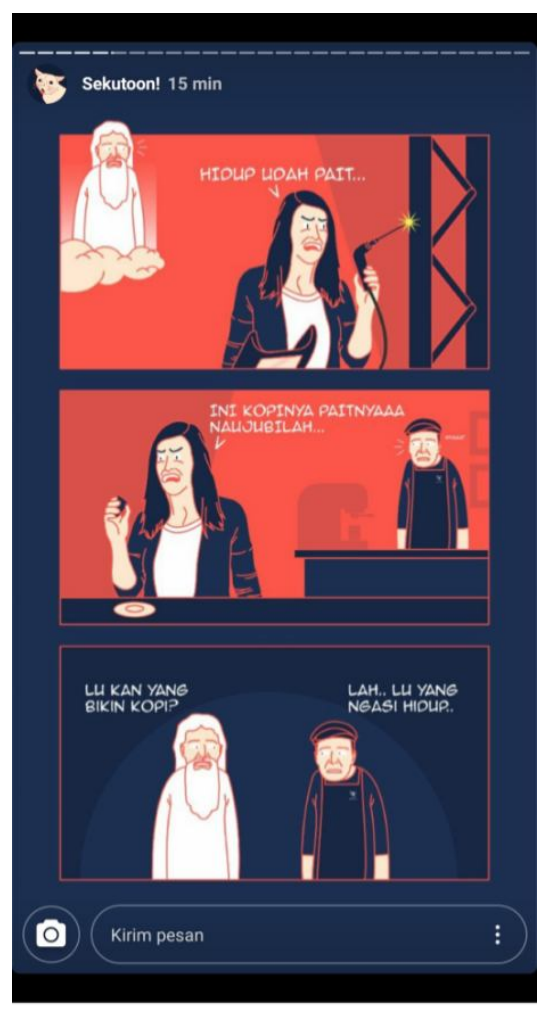

4

Gambar 4. Cara Sekutu Kopi menanggapi feedback pelanggan

(Sumber: Instagram Sekutu Kopi,2019)

f. Media

Media sosial apa saja yang digunakan dan apa saja yang perlu diperhatikan saat melakukan promosi melalui media sosial. Media yang dipilih Sekutu Kopi yang paling diutamakan adalah instagram dan fokus untuk segala aspek promosi dan iklan hanya di instagram, karena menurut Gege Saga instagram adalah sarana yang paling tepat untuk digunakan dengan berbagai alasan yang mendukung.

"Untuk sekarang ini media sosial kita ada 3 yaitu Instagram, Facebook, dan Whatsapp, yang mana kita fokus utama promosi adalah menggunakan Instagram sedangkan Facebook dan Whatsapp kita gunakan sebagai media pendukung promosi. tapi sekarang ini media yang diutamakan hanya ditunjukan ke Instagram karena selain jangkauan khalayak yang sangat luas, banyak fitur Instagram yang sangat menolong kami dalam merancang promosi di media sosial. Apalagi sekarang ini Instagram adalah media sosial yang memiliki pengguna aktif 
terbanyak. Target sasaran kami juga hampir seluruhnya adalah pengguna aktif Instagram, untuk media sosial lain seperti Facebook dan Whatsapp, kami gunakan untuk mendukung promosi selain Instagram. Kalau di Facebook sebenarnya kami tidak banyak posting tapi kami menyediakan sarana untuk menjangkau target pasar yang tidak mengikuti kegiatan kami di Instagram. Sedangkan untuk Whatsapp sifatnya lebih personal. Biasanya pelanggan akan menghubungi kami via Whatsapp untuk menanyakan pertanyaan-pertanyaan yang sifatnya lebih personal atau mungkin karena pelanggan tidak ingin percakapannya terekspos di Instagram karena fitur komen dapat dilihat oleh orang banyak. Pelanggan yang menghubungi via W hatsapp biasanya menghubungi kami untuk menanyakan jam operasional pada hari-hari akhir pekan atau hari raya, ada juga yang menanyakan soal daftar harga." (Wawancara dengan Gege Saga, 2019)

\section{g. Arah Kreatif}

Arah kreatif Sekutu Kopi adalah sebuah gaya penyampaian pesan yang digunakan untuk berkomunikasi dengan pelanggan. Dengan gaya penyapaian yang khas, unik, serta sesuai dengan harapan targetnya, diharapkan audiens iklan juga merespon pesan sesuai dengan harapan Sekutu Kopi. Kedai Sekutu Kopi memiliki cara berkomunikasi dengan pelanggan yang unik, hal ini menjadi salah satu arah kreatif yang digunakan secara konsisten selama kegiatan promosi.

“Cara penyampaian pesan atau respon pelanggan di media sosial kami usahakan seinformatif mungkin. Kami juga menggunakan cara kami sendiri ketika berhadapan dengan pelanggan yang memberikan kritik kepada kami. Apabila kritik dan saran yang disampaikan pelanggan dinilai membangun untuk kami, maka kami akan sangat berterima kasih atas perhatian pelanggan terhadap kesalahan dan kekurangan kami sehingga kami akan mengkoreksi apa yang menjadi perhatian mereka. Tapi apabila kritik yang diberikan tidak membangun dan hanya sekedar disampaikan untuk menyindir atau bahkan membandingkan kami dengan kompetitor kami yang lain maka kami juga tidak akan ragu dalam membalas feedback pelanggan tersebut dengan respon berbumbu sarkasme dan hal ini tidak jarang terjadi. Walaupun respon yang kami berikan kepada pelanggan beragam, kami merasa bahwa kami harus memberikan feedback dan respon sebaik mungkin." (Wawancara Gege Saga, 8 Juli 2019)

"Balasan yang diberikan kepada pelanggan tidak hanya melalui kata-kata saja namun juga kami kembangkan menjadi pesan yang disampaikan secara visual. Seperti komik strip atau sticker pada pesan balasan respon pelanggan. Dengan adanya variasi pesan yang ditambahi dengan visual ini, kami rasa akan menarik perhatian karena mereka akan lebih memperhatikan gambar terlebih dahulu daripada tulisan. Untuk desain pesan visualnya diusahakan sederhana namun menarik. Sehingga fokus pesan tidak hanya pada visualnya saja tapi juga pada pesan verbalnya. Jika hanya gambar saja seringkali tidak akan tersampaikan dengan baik maksud dari pesan kami, begitu juga apabila pesan yang disampaikan secara verbal terus menerus, orang-orang yang melihat tulisan terus akan cepat bosan ketika harus membaca tulisan tanpa ada visual yang mendukung." (Wawancara Christopher Dimaz, 10 Juli 2019) 


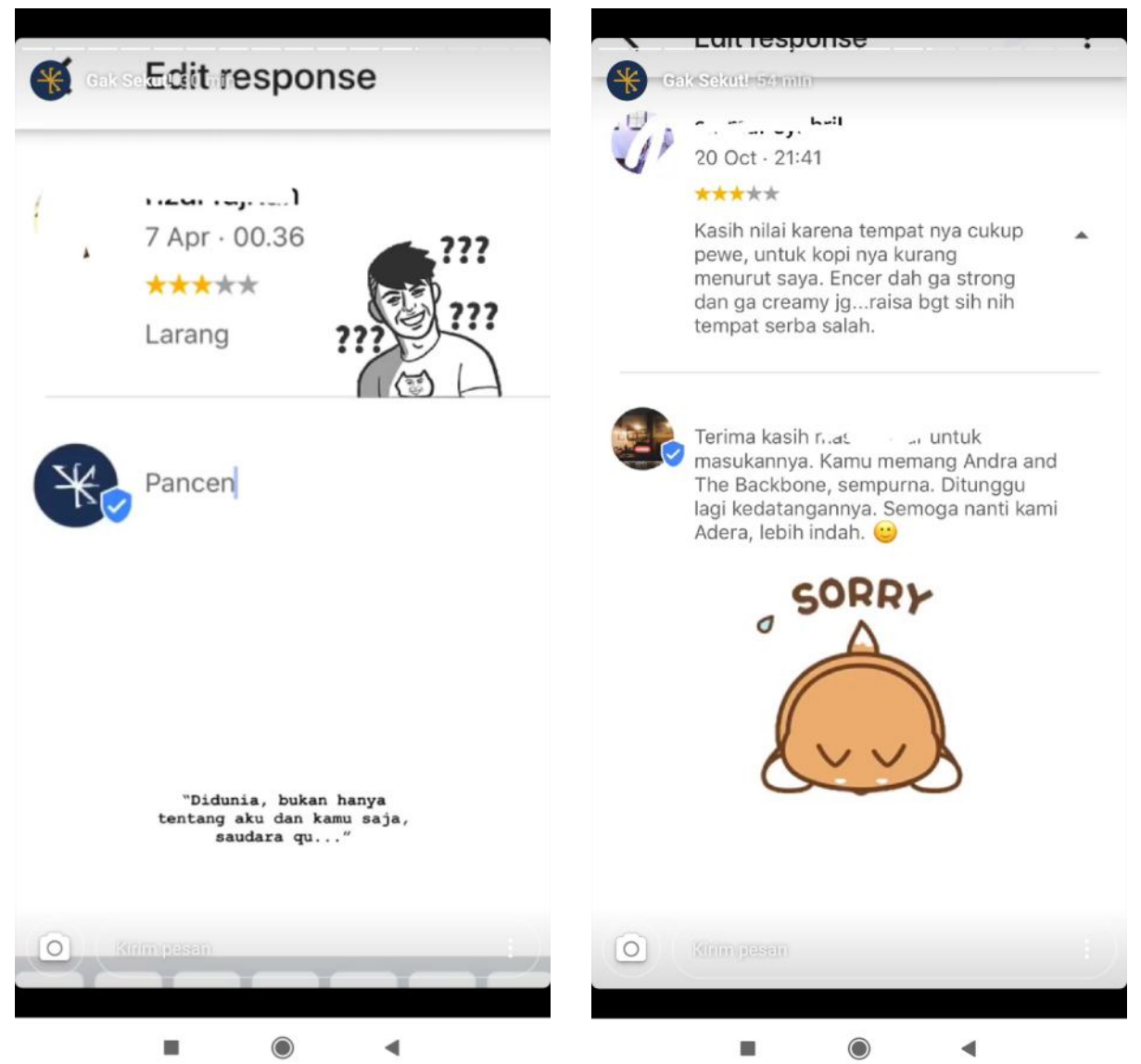

Gambar 5. Respon Sekutu Kopi terhadap kritik dari pelanggan (Sumber: Instagram Sekutu Kopi,2019)

\section{Strategi Pesan Dalam Promosi Di M edia Sosial Instagram}

Membuat sebuah iklan yang tepat kepada sasaran membutuhkan beberapa peranan proses kreatif didalamnya. Penyampaian pesan merupakan salah satu aspek yang berperan penting dalam sebuah iklan promosi. Pembentukan pesan tentang suatu produk pada prinsipnya merupakan manfaat utama yang ditawarkan merek sebagai pengembangan konsep sebuah produk. Pesan iklan harus disampaikan secara kreatif, dan iklan promosi yang dibuat harus memiliki keunikan tersendiri agar memiliki efek dalam benak target sasaran yang dituju, pesan kreatif yang akan disampaikan seperti apa, media apa saja yang akan digunakan, serta eksekusi pembuatan iklan promosi yang disesuaikan dengan gaya yang diinginkan dan proses kreatif yang dimatangkan.

Proses kreatif dalam pembuatan pesan promosi Sekutu kopi memiliki beberapa aspek yang memiliki peran penting atas tercapainya tujuan promosi dan memiliki keunikan lain yang tidak ditemui di media sosial kompetitor sejenisnya. Aspek tersebut yaitu : 
a. Jenis iklan yang digunakan

Sekutu Kopi mengambil beberapa jenis iklan yang tergolong dalam kriteria iklan yang digunakan untuk promosi, yaitu iklan informatif, iklan persuasif, dan iklan penambah nilai.

b. Pesan yang disampaikan dalam iklan promosi

Jenis pesan yang disampaikan pada setiap iklan Sekutu Kopi merupakan pesan yang memiliki kesan persuasif dan provokatif positif. Berarti pesan yang disampaikan cenderung bersifat ajakan atau membujuk bagi pembaca serta menimbulkan rasa ingin tahu dan minat pelanggan terhadap produk yang ditawarkan.

c. Creative brief Sekutu Kopi

Proses kreatif di Sekutu Kopi seringkali diawali dengan adanya creative brief, baik dengan formasi lengkap bersama pemilik atau hanya antara Creative Director dengan Graphic D esigner saja. Pada proses ini, akan dibahas mengenai banyak hal menyangkut proses promosi, iklan, event, dan lain-lain.

d. Proses desain Sekutu Kopi

Ketika sebuah proses desain akan dilakukan, maka creative brief dari desain yang akan dibuat sudah dimengerti oleh Graphic Designer yang akan bertanggung jawab atas proses pengerjaannya. Pembuatan iklan promosi di media sosial bersifat fleksibel, yang artinya Shareholder Sekutu Kopi (M anagement Director dan Operational Director) tidak akan selalu memberi peraturan atau memerlukan arahan khusus pada setiap desain iklan promosi yang akan dipublikasikan. Creative Director dibantu dengan Graphic D esigner diberi kepercayaan untuk merancang iklan promosi dan segala proses desain yang diperlukan asalkan sesuai dengan ketentuan iklan kreatif. Berikut ini kriteria iklan kreatif menurut Zein Mufarrih:

1. Unik dan Beda

2. Mudah Diingat

3. Asli

4. Memiliki Efek

5. Mengejutkan

6. Sifat Kebaruan

Strategi pesan dalam iklan promosi memang harus dirancang secara kreatif, dengan demikian tujuan dari iklan promosi akan tercapai karena telah dilakukan sesuai dengan 
eISSN 0000-0000

p-ISSN 0000-0000

Vol. 00, A pril 2020

prosedur yang ditetapkan. Tujuan utama dari strategi pesan periklanan promosi adalah tercapainya tujuan tersebut melalui iklan promosi yang dibuat. Sebuah iklan yang efektif harus diiringi dengan perencanaan iklan promosi yang matang. Hal ini dilakukan agar Segala aktivitas promosi memiliki arah yang sejalan dengan tujuan promosi, Mendapatkan hasil akhir yang maksimal, Memberikan dasar landasan bagi evaluasi kegiatan promosi dan pengawasan proses kreatif

Berikut ini adalah strategi pesan Sekutu Kopi sebagaimana seperti yang diungkapkan oleh Gege Saga, sesuai dengan ketentuan $5 \mathrm{~W} 1 \mathrm{H}$ :

a. What: A pa tujuan iklan promosi?

Tujuan utama dari periklanan Sekutu Kopi tentu saja untuk membangun kesadaran publik atas kehadirannya di kota Solo sebagai kedai kopi lokal terbaik. Dalam iklan promosi ini, Sekutu Kopi selalu berusaha menawarkan sesuatu yang baru, fresh, dan unik kepada masyarakat pecinta kopi di kota Solo. Selain informasi tentang bidang usaha yang dijalankan, Sekutu Kopi juga akan menunjukkan identitas brand mereka sebagai yang terbaik dibidangnya. Tidak hanya untuk mempromosikan produk kopi, Sekutu Kopi juga menjadikan iklan sebagai sarana untuk mengedukasi masyarakat kota Solo yang masih asing dengan dunia dibalik layar bisnis kopi. Sehingga tidak hanya bertujuan untuk menjual kopi, Sekutu Kopi juga memberikan benefit berupa pengetahuan tentang pengolahan kopi, proses seleksi kopi, serta jenis-jenis biji kopi melalui acara-acara workshop yang mengundang Sekutu Kopi sebagai salah satu narasumbernya.

b. Who: Siapa target sasarannya?

Target sasaran dari iklan promosi media sosial Instagram adalah kaum milenial yang hampir seluruhnya memiliki akun Instagram aktif. Tidak hanya anak muda, orang dewasa juga menjadi target sasaran kami dengan rentang usia yang berkisar antara 1745 tahun. Jadi, seluruh pengguna media sosial Instagram seluruhnya bisa saja menjadi target sasaran Sekutu Kopi. Target sasaran ini dipilih berdasarkan usia konsumsi kopi terbanyak, pengguna Instagram dengan usia produktif, serta minat target pasar akan sesuatu yang berbau kopi.

c. When: Kapan iklan promosi dipublikasikan?

Ketepatan waktu dalam posting melalui Instagram biasanya akan dilakukan pada waktu dimana biasanya pengguna media sosial akan memiliki waktu luang disela-sela kesibukan pagi hari, siang hari saat beristirahat, ataupun sore hari ketika pulang bekerja 
atau belajar. Karena kebiasaan ngopi setiap orang berbeda-beda, maka pemilihan timing untuk mempublikasikan konten iklan promosi ini harus sesuai dengan waktu yang tepat sesuai dengan perkiraan

"Ketika akan posting iklan, ditunggu saat yang tepat untuk mempost sesuatu yang dapat membuat mereka (audiens iklan) tergerak untuk mencoba atau menimbulkan gagasan "ngopi" dalam benak mereka ketika melihat iklan kita." (Wawancara Gege Saga, 8Juli 2019)

d. Where: Dimana iklan promosi dipasang?

Sekutu Kopi memfokuskan diri untuk melakukan segala kegiatan promosi melalui Instagram. Karena, menurut Creative Director dan Shareholder Sekutu Kopi, media yang paling tepat dan efektif untuk beriklan saat ini adalah dengan menggunakan Instagram (@sekutukopi).

“Untuk sekarang ini memang cuma pakai Instagram. Karena target pasar, fitur penunjang yang lengkap dalam satu media, serta waktu yang dibutuhkan untuk memposting hanya memerlukan sedikit waktu yang relatif singkat. Dengan keuntungan ini, Instagram kami pilih sebagai media promosi utama saat ini." (Wawancara Carissa Odilia, 8Juli 2019)

e. Why: Mengapa promosi melalui media sosial Instagram?

Promosi dilakukan di media sosial Instagram karena Instagram sekarang ini adalah media sosial terbesar kedua yang digunakan setelah Facebook dengan total jumlah pengguna aktif terbanyak. Dengan alasan ini, Instagram menjadi lahan iklan promosi yang baik untuk Sekutu Kopi karena persebaran informasi sangat cepat antar satu pengguna dengan yang lainnya.

"Soalnya ketika satu pengguna Instagram merepost iklan promosi kami, teman dekat atau orang-orang yang saling mengikuti dengan mereka akan dapat melihat juga iklan yang direpost. A palagi hampir seluruh usia produktif penikmat kopi adalah pengguna Instagram aktif, jadi dengan banyaknya kesamaan dan kemudahan yang sudah ada kami manfaatkan sebaik mungkin. Instagram menjadi cara tercepat kami dalam menjangkau target pasar dan audiens yang luas." (Wawancara Gege Saga, 8 Juli 2019)

f. How: Bagaimana bentuk iklan promosi di Instagram?

Bentuk iklan Sekutu Kopi di Instagram juga merupakan strategi kreatif yang dapat menarik perhatian audiens media sosial Instagram dengan ciri khas yang dimiliki. Iklan promosi Sekutu Kopi di Instagram umumnya memuat foto, caption, dan hashtag serta desain khas Sekutu Kopi.

"Saat membuat iklan di Instagram biasanya kita menciptakan kecocokan foto yang kami gunakan dengan caption yang persuasif, provokatif, atau hanya kalimat- 
kalimat puitis. Dari segi foto kita usahakan selalu dengan gaya khas Sekutu Kopi beserta nilai estetik yang menjadi identitas kami." (Wawancara Ricky Vernandes, 8 Juli 2019)

\section{Elemen Dan Unsur Iklan Promosi Sekutu Kopi}

Iklan promosi Sekutu Kopi terbangun dari beberapa komponen yang disatukan sehingga dapat terbentuk iklan kreatif. Beberapa elemen dan unsur tersebut diantaranya:

a. Logo

Logo merupakan salah satu identitas merek yang harus dicantumkan dalam iklan promosi yang digunakan. Menurut Ari Nurrohman menyatakan bahwa logo berguna sebagai sebuah pengembangan suatu merek karena citra merek menyangkut reputasi dan kredibilitas merek yang menjadi pedoman bagi khalayak konsumen untuk mencoba atau menggunakan suatu produk barang atau jasa sehingga menimbulkan pengalaman tertentu (brand experience) yang akan menentukan apakah konsumen tersebut akan menjadi loyalis merek atau hanya sekedar oportunis (mudah berpindah ke merek lain). (Nurrohman, 2015;128) Logo Sekutu Kopi memiliki karakter yang simple, modern, dan memiliki tingkat keterbacaan yang tinggi. Simpel artinya memiliki nilai-nilai yang sederhana namun tetap dapat menampilkan kesan elegan, berkelas, dan mudah diterima oleh masyarakat sehingga usaha promosi dengan mudah akan diserap oleh benak audiens iklan. Sementara Modern berarti selalu mengikuti perkembangan jaman sehingga setiap unggahan post Instagram yang dibagikan kepada audiens iklan selalu memiliki hal yang baru

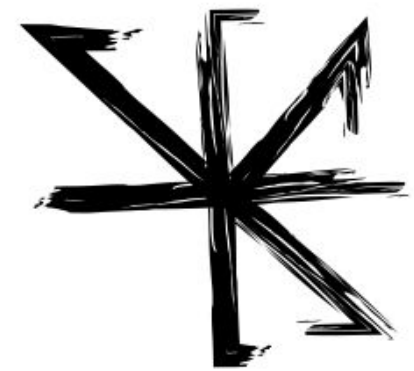

\section{SEKUTU KOPI}

Gambar 6. Logo Sekutu Kopi

(Sumber: Instagram Sekutu Kopi,2019) 
b. Ilustrasi/ Foto

Ilustrasi atau foto merupakan elemen desain yang sering dijumpai dan digunakan. Ilustrasi atau foto harus selaras atau saling melengkapi dengan tema dan isi pesan yang ada di iklan promosi Instagram. Ilustrasi yang digunakan dalam konten iklan tidak hanya menggunakan model manusia namun juga memanfaatkan suasana coffeeshop, peralatan, dan produk yang akan dijual.

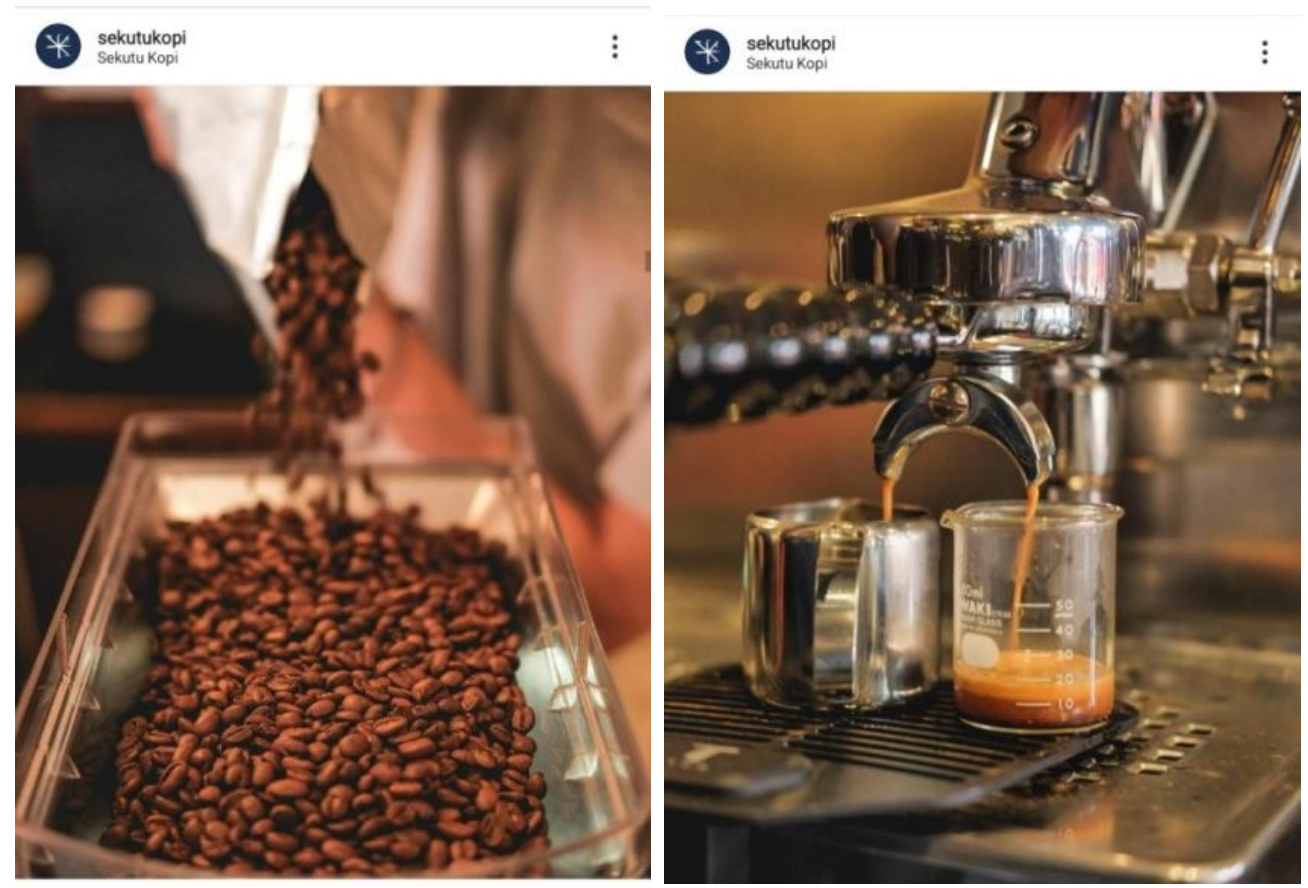

Gambar 7. Foto-foto dalam Instagram Sekutu Kopi

(Sumber: Instagram Sekutu Kopi,2019)

c. Caption/ Isi Pesan

Seluruh iklan promosi Sekutu Kopi di Instagram memiliki caption/ isi pesan didalamnya. Kegunaan dari isi pesan tambahan ini adalah sebagai penggerak atau sarana persuasif untuk mempengaruhi audiens iklan agar merespon isi pesan yang disampaikan. Isi pesan pun dapat memiliki tipe yang berbeda-beda sesuai dengan kebutuhan promosinya. Isi pesan yang disampaikan bermakna persuasif atau seperti ajakan untuk ikut melakukan kegiatan yang diadakan di kedai Sekutu Kopi atau untuk datang dan singgah. Beberapa isi pesan juga memiliki sisi informatif untuk audiens iklannya mengenai kegiatan dalam kedai. 


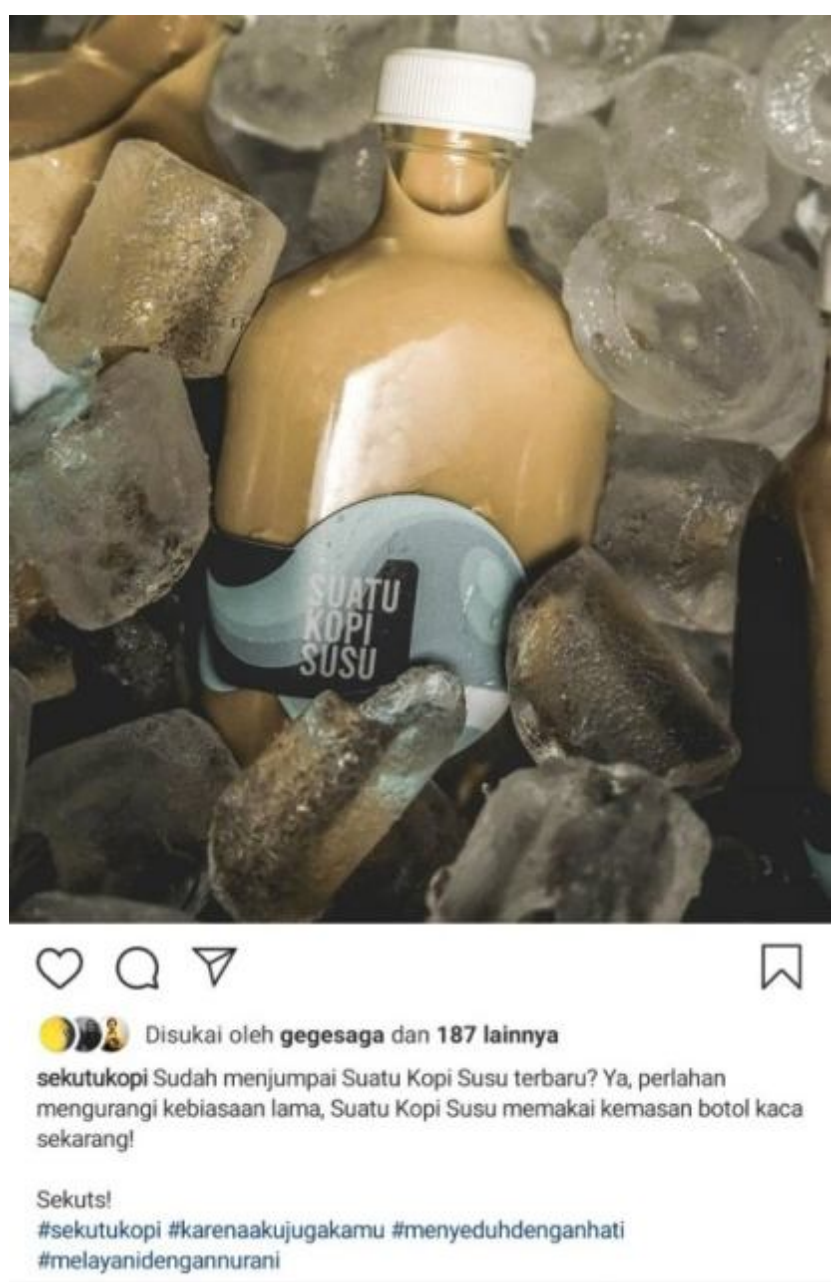

Gambar 8. Caption dalam Instagram Sekutu Kopi

(Sumber: Instagram Sekutu Kopi,2019)

d. Layout

Layout merupakan unsur penting dalam sebuah iklan promosi secara visual media promosi, karena layout memiliki fungsi untuk mengatur tata letak gambar, isi pesan, foto, serta materi penunjang lainnya dalam visual iklan promosi tersebut. Layout berkaitan dengan pengaturan tipografi, dan tata visual pada permukaan 2 dimensi agar seluruh informasi dapat dibaca, jelas, dan menarik perhatian. Layout juga merupakan pengatur elemen-elemen pada sebuah desain, hingga terbentuk rancangan iklan promosi yang diharapkan. Penataan tata letak desain dan tipografi serta gambar atau foto memiliki letak yang berbeda-beda. Penataan letak yang tidak selalu sama ini dilakukan dengan tujuan agar iklan promosi dan feed Instagram menjadi tidak membosankan dengan banyaknya variasi, menarik untuk dilihat, serta menunjukkan sisi kreatif yang berbagai macam bentuknya. 
e. Warna

Warna memiliki daya tarik tersendiri ketika diaplikasikan sebagai tema untuk iklan promosi. A pabila warna yang digunakan cerah, maka akan timbul kesan bersih, cerah, dan ceria. A pabila warna yang digunakan adalah warna gelap maka akan menampilkan kesan yang klasik, glamor, elegan, dan tenang. Penggunaan warna dan pemilihan warna harus disesuaikan dengan isi pesan yang ingin disampaikan karena warna memiliki arti tersendiri baik dalam artian secara psikologis ataupun sebagai daya tarik sebuah iklan promosi. Berikut ini adalah macam-macam warna yang digunakan oleh Sekutu Kopi dalam desain iklan promosi Instagram beserta artian warna menurut C.S Jones:

Warna hitam bersifat menekan, gelap, kekuatan, kemewahan, kecanggihan, tegas, klasik, dan eksklusif

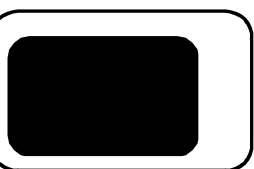

Warna putih bersifat murni, polos, sederhana, absolut, steril, minimalis, bersih, damai, modern, sempurna, ringan, dan semangat

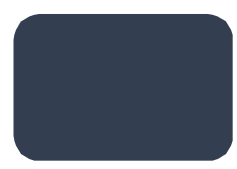

Warna biru tua (navy) bersifat dingin, damai, kebersamaan, dapat dipercaya, tenang, teratur, serius, dan konservatif

\section{KESIMPULAN}

Sekutu Kopi merupakan sebuah usaha yang bergerak di bidang Coffee Shop dan merupakan salah satu yang terkenal di Kota Solo dengan target pasar masyarakat pecinta kopi usia produktif dan aktif dalam sosial media. Pendekatan kreatif yang digunakan oleh Sekutu Kopi dalam perancangan strategi kreatif periklanan untuk kegiatan promosinya yaitu melalui jenis iklan informatif, iklan persuasif, dan iklan penambah nilai yang juga memberikan suatu provokasi secara emosional kepada masyarakat yang melihat iklan dengan teks, gambar, ilustrasi, dan foto.

Strategi kreatif dalam iklan promosi Sekutu Kopi dirancang dan dikerjakan dengan creative brief yang akan menjadi pedoman dalam pembuatan iklan tersebut. Sekutu Kopi 
eISSN 0000-0000

p-ISSN 0000-0000

Vol. 00, A pril 2020

telah menganalisis beberapa tahapan yang harus diperhatikan dalam konsep yang akan mereka ambil, antara lain sebagai berikut. (1) Permasalahan, (2) Survey Khalayak, (3) Posisi Brand, (4) Tujuan Komunikasi, (5) Media, (6) Arah Kreatif. Strategi pesan yang dilakukan oleh Sekutu Kopi juga memiliki berbagai elemen-elemen penting yang akan membentuk suatu pesan kreatif untuk mengiklankan produknya kepada masyarakat luas. Pesan utama yang ingin disampaikan adalah untuk mengajak masyarakat menikmati kopi bersama Sekutu Kopi, selain banyaknya event-event khusus dan educational program yang dilaksanakan oleh Sekutu Kopi untuk masyarakat.

Analisis yang dilakukan terhadap konsep kreatif Sekutu Kopi menghasilkan sebuah konsep yang modern dan simple. M odern yang berarti mengedepankan perubahan terhadap trend yang akan terus berubah seiring berjalannya waktu dan perubahan gaya hidup. Simple yang berarti kesederhanaan dalam cara penyampaian namun tetap memiliki banyak informasi penting didalamnya, seperti (1) logo yang simple, (2) penggunaan ilustrasi atau foto berkonsep khas Sekutu Kopi, (3) pemilihan tipografi yang memiliki bentuk huruf sederhana, dan memiliki keterbacaan yang baik, (4) layout iklan promosi yang konsisten sesuai dengan ciri khas Sekutu Kopi, (5) penggunaan warna-warna khas Sekutu Kopi agar identitas Sekutu Kopi terus terjaga sesuai dengan konsep yang diterapkan.

Pemakaian media sosial Instagram sebagai media promosi online utama Sekutu Kopi dikarenakan Instagram menjadi salah satu media sosial yang sangat populer dan paling sering digunakan oleh masyarakat sekarang ini, fitur pada Instagram juga sangat banyak sehingga sangat mendukung kegiatan promosi Sekutu Kopi secara online, serta pengguna aktif terbanyak yang berarti bahwa audiens iklan sangat luas. Alasan lain mengapa Sekutu Kopi memilih menggunakan media sosial sebagai media promosi adalah untuk meminimalkan anggaran dana dalam kegiatan promosi agar tidak melampaui budget yang telah ditetapkan namun tetap maksimal dalam promosi melalui media sosial Instagram.

\section{DAFTAR PUSTAKA}

Andriani, Sherly. 2017. Sikap Masyarakat Surabaya Mengenai Iklan Magnum Wall's “Taste The Classic". Jurnal E-Komunikasi. Vol. 5 No.2, hal.5.

Berger, Arthur Asa. 1993. An Anatomy of Humor. United States of America. Transaction Publisher.

Bonafix, D. Nunnun. 2011. Videografi: Kamera Dan 3Teknik Pengambilan Gambar. Jurnal H umaniora. Vol.2. No. 1, hal.845-854. 
Gumbiro Banjaransari, Yudhi. 2018. Pemanfaatan instagram sebagai media komunikasi pemasaran online page down cl oth maker. Tugas A khir. Universitas Muhammadiyah Surakarta Kotler, Philip. Amstrong, Gary. 1997. D asar-dasar Pemasaran. Jakarta: Prenhallindo.

Lim, Sook Huey and Yazdanifard, Rashad. 2016. H ow Instagram can be used as a tool in social networking marketing. Center for Southern New Hampshire University (SNHU) programs Help Cologe of Art and Technology. Kuala Lumpur, Malaysia. http:/ / www.researchgate 20 net/ publication/ 265377226

Mufarrih, Zein. 2015. Periklanan Sebuah Pendekatan Praktis. Yogyakarta: Buku Litera.

Murfianti, Fitri. 2017, Photo: Identity and Commodity On Social Media Instagram. Proceeding The 2nd Annual of International and Interdisciplinery Conference on Arts Creation and Studies, 14-15 October 2017, ISI Pers, ISBN 978-602-61933-7-7, hal 153-159 Murfianti, Fitri. 2010, Membangun City Branding melalui Solo Batik Carnival, Jurnal A cintya, Vol.2 N o.1, ISI Pers, ISSN CETAK: 2085-2444, https:/ / doi.org/ 10.33153/ acy.v2i1.101 Nasrulah, Rulli. 2016. M edia sosial (prespektif komunikasi, budaya, dan sosioteknologi). Bandung: Simbiosa Rekatama Media.

Nurrohman, Ari. 2015. Studi komparasi desain poster dalam strategi promosi rown division dan pined wearhouse perigee sebagai fashion store di kota solo. Tugas Akhir Skripsi Universitas Sahid, Surakarta

Permatasari, Gita. Hapsari, Dwi Retno. 2016. Efektivitas media sosial instagram sebagai media promosi produk olahan pertanian yoghurt cimory. Institut Pertanian Bogor. http:/ / repository.ipb.ac.id/ handle/ 123456789/ 81930

Sugiarto, Vania Dewi. 2016. Teknik Humor Dalam Film Komedi Yang Dibintangi Oleh Stand Up Comedian. Jurnal E-K omunikasi.Vol. 4 No.1, hal 1-12.

Tjiptono, Fandy. 2005. Pemasaran Jasa. Malang: Bayumedia Publishing. 